\title{
EVALUATION OF THE REACTION OF WATERMELON PARENT AND F PLANTS TO Meloidogyne enterolobii ${ }^{1}$
}

\author{
LÉIA SANTOS DAMACENO ${ }^{2 *}$, MANOEL ABÍLIO DE QUEIROZ ${ }^{2}$, RITA DE CÁSSIA SOUZA DIAS ${ }^{3}$, JOSÉ MAURO \\ DA CUNHA E CASTRO ${ }^{4}$, FÁTIMA ALVES TEIXEIRA ${ }^{5}$
}

\begin{abstract}
The aim of this study was to evaluate the performance of progenies from Citrullus lanatus var. lanatus (cultivated watermelons) when crossed with progenies from C. lanatus var. citroides (fodder watermelon with a historic of resistance to the nematode Meloidogyne enterolobii). The parents and their $\mathrm{F}_{1 \mathrm{~s}}$ were evaluated for resistance to this nematode. In the initial stages of eleven treatments, watermelon seedlings plantlets were transplanted to plastic bags of six kilograms once the first leaves developed. Ten inoculated plants with 5,200 eggs in the soil near the stem of the plant and four non-inoculated ones were used in each treatment, in a complete block design. Sixty-two days after sowing, the following characteristics were evaluated: the length of the aerial part of the plant (LAP, in m), fresh mass of the aerial part (FMAP, in g), root fresh mass (RFM, in g), egg number (EN) and reproduction factor (RF). A comparison between the averages of inoculated and non-inoculated plants was performed using Scott-Knott test at 5\% and the diallelic analysis was performed using the GENES program. The morphological characteristics did not allow for the identification of the parent plants or the $F_{1 \mathrm{~s}}$ with respect to nematode resistance, but the variables EN and RF were useful for such identification. The analyses of the general and specific combining abilities indicate highly significant effects with respect to this resistance, showing additive gene effects as well as dominance and epistatic gene effects, allowing for identification of parents and $F_{1 s}$ that can be used in watermelon breeding programs to improve resistance to the M. enterolobii.
\end{abstract}

Keywords: Citrullus spp. Root-knot nematode. Watermelon breeding.

\section{AVALIAÇÃO DE PARENTAIS E F 1 SM MELANCIA QUANTO À REAÇÃO AO Meloidogyne enterolobii}

\begin{abstract}
RESUMO - O objetivo deste estudo foi avaliar o desempenho de progênies de melancia provenientes de Citrullus lanatus var. lanatus (melancias cultivadas) quando cruzadas com progênies provenientes de $C$. lanatus var. citroides (melancias forrageiras com histórico de resistência ao nematoide Meloidogyne enterolobii). Os parentais e seus $\mathrm{F}_{1 \mathrm{~s}}$ foram avaliados quanto à reação a esse nematoide. Mudas de melancia de onze tratamentos no estádio inicial, com a primeira folha definitiva recém desenvolvida foram plantadas em sacos plásticos de seis quilogramas. Utilizou-se dez plantas inoculadas com 5.200 ovos próximo ao colo da planta e quatro não inoculadas em cada tratamento em um delineamento inteiramente casualizado. Após 62 dias foram avaliados os seguintes caracteres: comprimento da parte aérea (CPA, em m), massa fresca da parte aérea (MFPA, em g), massa fresca de raiz (MFR, em g), número de ovos (NO) e o fator de reprodução (FR). A comparação das médias das plantas inoculadas e não inoculadas foi feita usando o teste de Scott-Knott ao nível de 5\%. A análise dialélica foi realizada utilizando-se o programa GENES. Os caracteres morfológicos não permitiram identificar as plantas dos parentais e dos $\mathrm{F}_{1 \mathrm{~s}}$ quanto à reação ao nematóide, porém, as variáveis $\mathrm{NO}$ e FR foram eficientes nessa identificação. A análise das capacidades geral e específica de combinação indicou efeitos altamente significativos quanto a essa reação, mostrando efeitos gênicos aditivos e também efeitos de dominância e epistáticos, permitindo identificar pais e $F_{1 s}$ para serem usados em programas de melhoramento de melancia para resistência ao M. enterolobii.
\end{abstract}

Palavras-chave: Citrullus spp. Nematoide-das-galhas. Melhoramento de melancia.

\footnotetext{
Corresponding author

${ }^{1}$ Received for publication in $08 / 29 / 2014$; accepted in $01 / 19 / 2016$.

Paper extracted from the master's dissertation of the first author.

${ }^{2}$ Department of Technology and Social Sciences, Universidade do Estado da Bahia, Juazeiro, BA, Brazil; leiadama@hotmail.com, manoelabiliomaq@gmail.com.

${ }^{3}$ Genetic Resources and Plant Breeding, Empresa Brasileira de Pesquisas Agropecuária - Embrapa Semiárido, Petrolina, PE, Brazil; rita.dias@embrapa.br.

${ }^{4}$ Department of Nematology, Empresa Brasileira de Pesquisas Agropecuária - Embrapa Semiárido, Petrolina, PE, Brazil; mauro.castro@embrapa.br.

${ }^{5}$ Department of Food Technology, Instituto Federal de Educação Ciência e Tecnologia do Maranhão, Zé Doca, MA, Brazil; fatimateixeira_pe@hotmail.com.
} 


\section{INTRODUCTION}

In 2012, Brazil was ranked fourth in global production of watermelon, Citrullus lanatus (Thunb.) Matsum and Nakai var. lanatus, with a total of 2,079,547 tons produced (FAOSTAT, 2014). However, despite this high production, infections from fungi, bacteria, viruses, and nematodes cause plant diseases and biotic stress that reduce both productivity and fruit quality (SANTOS et al., 2005; SILVEIRA et al., 2005). Among these pathogens, plant-parasitic nematodes (phytonematodes that infest the root system of the watermelon plants) of the genus Meloidogyne not only cause irreparable losses in watermelon fields, but also it may create environmental damage if nematocides are applied. Then, residual effects can occur, as well as the possibility of chemical residues remaining on the fruit. The pathogen Meloidogyne enterolobii was found to parasitize guava plants in the Lowermiddle San Francisco area of Bahia, Brazil, and has since also been identified as a parasite affecting various vegetable crops in other regions of Brazil (CARNEIRO et al., 2006; BITENCOURT and SILVA, 2010; ALMEIDA et al., 2011), including beans, sun hemp (GUIMARÃES et al., 2003), and others. Though there are no published studies addressing parasitism of $M$. enterolobii in watermelon, samples of infected roots sent by producers to the Nematology Laboratory at the Semi -Arid Research Center of the Brazilian Agricultural Research Corporation (Embrapa) (CASTRO, 2014, personal communication) indicate that this nematode is parasitizing watermelon roots.

A sustainable and safe way to allow watermelon cultivation in areas infested with nematodes is the development of resistant cultivars. This requires identifying sources of resistance, and then inserting them into commercial varieties. The Active Germplasm Bank of Cucurbitaceae for the Brazilian Northeast contains watermelon accessions (QUEIRÓZ, 2004) such as the fodder watermelon, C. lanatus (L.H. Bailey) Mansf. var. citroides, a species that has shown resistance to various diseases in cultures (PONTES, 2009; CASTRO, 2014, personal communication), and the species $C$. colocynthis Schrad. (L.) A study by Pontes (2009) found that PI 244019 (C. lanatus var. citroides) from the United States was resistant to Meloidogyne mayaguensis (better known as M. enterolobii). Costa Filho (2012) studied resistance in watermelon accessions collected in the Brazilian state of Rio Grande do Norte and identified a large contrast in nematode egg production between accessions, as well as two accessions that are promising to be used as parents in a breeding program to develop cultivars for use in areas infested with parasitic nematodes. Costa Filho (2012) observed that these two watermelon accessions were more efficient in reducing the number of eggs. However, to date, the behaviour of parents and their $F_{1}$ progeny has not been studied with respect to resistance against the nematode $M$. enterolobii.

To select the parents in a breeding program, one of the methodologies commonly used is the use of diallel crosses (GORGULHO; MIRANDA FILHO, 2001). Within these, Griffing (1956) proposed that the effects of general and specific combining ability should be estimated (CRUZ; VENCOVSKY, 1989; CRUZ et al., 2012).

Therefore, the present study aimed to investigate the effects of the nematode $M$. enterolobii on vegetative development of watermelon, specifically accessions of $C$. lanatus var. lanatus, $C$. lanatus var. citroides, and the $\mathrm{F}_{1}$ progeny of a cross between accessions of these two varieties, to examine whether there is genetic complementarity of these genotypes with regard to resistance against attacks from this pathogen.

\section{MATERIALS AND METHODS}

The study was conducted in a greenhouse at the Bebedouro Experimental Station of the Semi-arid Research Center of the Brazilian Agricultural Research Corporation (Embrapa), located in Petrolina, state of Pernambuco, Brazil. The experiment to obtain the $F_{1}$ generation took place in the second half of 2011. The crosses were performed using three progenies of fodder watermelon $(C$. lanatus var. citroides) and two progenies of $C$. lanatus var. lanatus to obtain the $\mathrm{F}_{1}$ generation. Specifically, for C. lanatus var. lanatus, progenies of BGCIA $941\left(\mathrm{P}_{1}\right)$, BGCIA $240\left(\mathrm{P}_{2}\right)$, and BGCIA 229 $\left(\mathrm{P}_{3}\right)$ were used; for $C$. lanatus var. lanatus, progenies of two commercial varieties, line of cv. Smile $\left(\mathrm{P}_{4}\right)$ and line of cv. line BRS Opara $\left(\mathrm{P}_{5}\right)$, were used. The $\mathrm{F}_{1 \mathrm{~s}}$ from these crosses were: $\left(\mathrm{P}_{4} \times \mathrm{P}_{1}\right)$ - Progeny of cv. Smile x Progeny of BGCIA 941, $\left(\mathrm{P}_{4} \times \mathrm{P}_{2}\right)-$ Progeny of cv. Smile x Progeny of BGCIA $240,\left(\mathrm{P}_{4}\right.$ $\left.x \mathrm{P}_{3}\right)$ - Progeny of cv. Smile $x$ Progeny of BGCIA $229,\left(\mathrm{P}_{5} \times \mathrm{P}_{1}\right)$ - Progeny of BRS Opara x Progeny of BGCIA 941, $\left(\mathrm{P}_{5} \times \mathrm{P}_{2}\right)$ - Progeny of BRS Opara $\mathrm{x}$ Progeny of BGCIA 240 , and $\left(\mathrm{P}_{5} \times \mathrm{P}_{3}\right)$ - Progeny of BRS Opara $x$ Progeny of BGCIA 229. The BGCIA $941\left(\mathrm{P}_{1}\right)$, BGCIA $240\left(\mathrm{P}_{2}\right)$, and BGCIA $229\left(\mathrm{P}_{3}\right)$ progenies were used as pollen donors for the cultivated parents. The progenies and the parents that were used belong to the Active Germplasm Bank of Cucurbitaceae for the Brazilian Northeast, located at the Brazilian Semi-arid Agricultural Research Corporation (Embrapa) in Petrolina, Pernambuco, Brazil (QUEIRÓZ, 2004).

Ten plants from each parent were transplanted to the field, with each parent taken from a bulk of three to eight plants. During the flowering phase, controlled manual pollinations were performed. The average temperature during the first experiment (in the second half of 2011 ) ranged from $23.5^{\circ} \mathrm{C}$ to $26.7^{\circ}$ 
C. After maturation, the fruits were harvested and the seeds were extracted. When seeds were dry, they were put into paper bags in which the accession information was recorded and then stored in a cold chamber at $10^{\circ} \mathrm{C}$ and $40 \%$ humidity until use.

During the first half of 2012, under greenhouse conditions, inoculation of the parents and their respective $F_{1 s}$ was performed. Six $F_{1}$ hybrids and their respective parents (totalling 11 treatments) were seeded in polystyrene trays containing a commercial substrate mixture of vermiculite and vegetable ash. For each treatment, the seeds were from a progeny chosen at random. During the experimental period, the maximum temperature varied from $41.23^{\circ} \mathrm{C}$ to $43.34^{\circ} \mathrm{C}$, and the minimum temperature ranged from $22.28^{\circ} \mathrm{C}$ to $24.7^{\circ} \mathrm{C}$.

Inoculum was collected from phytonematode infected roots in guava (Psidium guajava L. cultivar Paluma) producing areas in the municipality of Petrolina, Pernambuco, and then properly identified at the Phytonematology Laboratory of the Semi-arid Research Center of the Brazilian Agricultural Research Corporation (Embrapa). Identification was determined through exposure to $\alpha$-esterase using the vertical electrophoresis technique in polyacrylamide gel (ALFENAS; BRUNE, 2006). The extraction of eggs from roots was performed according to the methodology of Coolen and D' Herde (1972) using an optical microscope and binocular magnifying glass.

The test was conducted using a completely randomized design in which a sample of ten plants for each of the 11 eleven treatments were inoculated and another sample of four plants for each of the 11 treatments were not inoculated and acted as specific controls. As a general control and to verify viability of the inoculum, three tomato plants (Solanum lycopersicum) were also inoculated. Each experimental unit consisted of one plant. Using a drip irrigation system and experimental units represented by one plant, the experiment was managed in accordance with the technical recommendations for culturing the watermelon crop.

Ten days after seeding, when the first leaves appeared, 10 plants were transferred to bags (experimental units) filled with six kilograms of a mixture of soil, sand and manure $(2: 1: 1 \mathrm{v} / \mathrm{v} / \mathrm{v})$, previously sterilized by autoclaving at a temperature of $120^{\circ} \mathrm{C}$ for 1 hour and 40 minutes.

Two days after transplantation into the bags, ten plants from each treatment were inoculated through a hole within two centimetres from the plant neck, with the aid of a wash bottle. It was used a 1 $\mathrm{mL}$ aliquot containing a suspension of 5,200 eggs per experimental unit.

Sixty-two days after inoculation, plant shoots were cut off at a height of two $\mathrm{cm}$ from the ground. The length of the aerial part of the plant (referred to as "LAP") was measured in meters, and the fresh mass of the aerial part (referred to as "FMAP") was measured in grams). Finally, the soil was removed carefully so that the root system could be recovered as much as possible, and be weighed to obtain the root fresh mass ("RFM") expressed in grams.

The roots were then placed in labelled plastic bags and sent to the Nematology Laboratory at EMBRAPA's Semi-arid Research Center, where they were refrigerated until egg extraction. The methodology used for the extraction and counting of eggs was the same as that used for extraction of the inoculum.

Once the number of eggs was determined, the reproduction factor (RF), the ratio of the final population (found in the root system) to the initial population (used in the inoculation), was determined. Plants with a RF $<1$ were considered resistant, while those with $\mathrm{RF} \geq 1$ were considered susceptible (MOURA; REGIS, 1987).

Mean values (LAP, FMAP, and RFM) for the inoculated and non-inoculated plants were compared using a t-test (GOMES, 2009), and the treatments were compared using the Scott-Knott test at a level of $5 \%$ probability with the aid of GENES software (CRUZ, 2013).

The GENES program (CRUZ, 2013) was used to perform diallel analysis according to the model of parents and $\mathrm{F}_{1}$, s, as modified by Geraldi and Miranda-Filho (1988). This method is characterized by the breakdown of the sum of squares of the treatments into sums of squares associated with the combining ability of partial diallels that include the parents (CRUZ et al., 2012), which were divided into two groups. Group I consisted of commercial watermelon progenies, and Group II consisted of fodder watermelon progenies.

The diallel variance analysis was performed according to the system presented by Cruz et al. (2012). It was used used the model: $Y=\mu+g_{i}+g_{j}+$ $\mathrm{s}_{\mathrm{ij}}+\mathrm{r}_{\mathrm{ij}}+\varepsilon_{\mathrm{ij}}$, where $\mathrm{Y}_{\mathrm{ij}}$ is the mean of the $\mathrm{h}(\mathrm{i} \neq \mathrm{j})$ or parent $(i=j) ; \mu$ is the overall average of the diallel; $g_{i}$ and $g_{j}$ are the effects of the general combining ability of the i-th or $\mathrm{j}$-th parent; $\mathrm{s}_{\mathrm{ij}}$ is the effect of specific combining ability to cross between the parents of order $\mathrm{i}$ and $\mathrm{j}$; and $\varepsilon_{\mathrm{ij}}$ is the experimental error.

\section{RESULTS AND DISCUSSION}

Length of the aerial part (LAP) and fresh mass of the aerial part (FMAP), as measured in all parent plants and $F_{1}$ progeny, showed no significant difference between inoculated plants and plants that were not inoculated. Root fresh mass (RFM) was significantly different for only three of five $F_{1 s}$ (Table 1). There was an increase in fresh root mass in inoculated plants for parent plants $\mathrm{P}_{4}$ and $\mathrm{P}_{5}$, and for the $\mathrm{F}_{1}$ combinations $\left(\mathrm{P}_{4} \times \mathrm{P}_{2}\right),\left(\mathrm{P}_{4} \times \mathrm{P}_{3}\right)$, and $\left(\mathrm{P}_{5}\right.$ $\mathrm{X} \mathrm{P}_{3}$ ); in these genotypes, an increase in the root fresh mass (RFM) could be observed due to formation of giant cells (galls), caused by the penetration and reproduction of nematodes on the 
roots of infected plants (COYNE et al., 2007; LOPES et al., 2008).

The variation in aerial plant length (LAP) between the progenies of plants exposed to the phytonematode was from 1.21 to $1.74 \mathrm{~m}$, and for plants that were not inoculated, the variation was from 1.24 to $1.83 \mathrm{~m}$; thus, the inoculated and noninoculated plants had similar values for this characteristic. For the fresh mass of the aerial part (FMAP) of inoculated plants, the range was from 69.4 to $173.1 \mathrm{~g}$, and for non-inoculated plants, the range was 95 to $200 \mathrm{~g}$, thus showing a greater influence of the nematode in reducing the mass of the aerial part of the plant. However, for root fresh mass (RFM), the range was between 5.44 to $21.40 \mathrm{~g}$. For non-inoculated plants, the RFM was much lower due to an absence of the galls caused by the phytonematodes (Table 1).

Thus, the only characteristic that differed between inoculated and non-inoculated plants was RFM. However, to perform this measurement, it is necessary to extract the root system and kill the plant, and this makes it impossible to conserve the genotype, which is eventually resistant.

Table 1. Mean aerial plant length (LAP), fresh mass of the aerial part (FMAP), and root fresh mass (RFM) of inoculated watermelon plants (IN) and non-inoculated watermelon plants (NI).

\begin{tabular}{|c|c|c|c|c|c|c|c|c|}
\hline \multirow{3}{*}{$\frac{\text { Treatment }}{\mathrm{P}_{4}}$} & \multirow{3}{*}{$\begin{array}{c}\mathrm{IN} \\
\mathrm{LAP}(\mathrm{m}) \\
1.21 \mathrm{bA}\end{array}$} & \multirow{2}{*}{\multicolumn{2}{|c|}{$\frac{\mathrm{NI}}{\mathrm{LAP}(\mathrm{m})}$}} & \multirow{2}{*}{$\frac{\text { IN }}{\text { FMAP (g) }}$} & \multirow{2}{*}{$\frac{\text { NI }}{\text { FMAP (g) }}$} & \multirow{2}{*}{$\frac{\text { IN }}{\text { RFM (g) }}$} & \multicolumn{2}{|c|}{ NI } \\
\hline & & & & & & & RF & $M(g)$ \\
\hline & & 1.41 & $\mathrm{Aa}$ & $96.00 \mathrm{bA}$ & $143.7 \mathrm{aA}$ & $8.36 \mathrm{bA}$ & 2.49 & $\mathrm{aB}$ \\
\hline $\mathrm{P}_{2}$ & $1.34 \mathrm{bA}$ & 1.24 & $\mathrm{aA}$ & $111.25 \mathrm{bA}$ & $126.25 \mathrm{aA}$ & $12.7 \mathrm{aA}$ & 17.25 & $\mathrm{aA}$ \\
\hline $\mathrm{P}_{4} \times \mathrm{P}_{2}$ & $1.64 \mathrm{aA}$ & 1.51 & $\mathrm{aA}$ & $173.12 \mathrm{aA}$ & $191.25 \mathrm{aA}$ & $13.98 \mathrm{aA}$ & 5.90 & $\mathrm{aB}$ \\
\hline $\mathrm{P}_{4}$ & $1.21 \mathrm{bA}$ & 1.41 & $\mathrm{aA}$ & $96.00 \mathrm{aA}$ & $143.75 \mathrm{aA}$ & $8.36 \mathrm{bA}$ & 2.49 & $\mathrm{aB}$ \\
\hline $\mathrm{P}_{3}$ & $1.37 \mathrm{bA}$ & 1.80 & $\mathrm{aA}$ & $91.50 \mathrm{aA}$ & 175 & $11.68 \mathrm{bA}$ & 6.05 & $\mathrm{aA}$ \\
\hline $\mathrm{P}_{4} \times \mathrm{P}_{3}$ & $1.65 \mathrm{aA}$ & 1.60 & $\mathrm{aA}$ & $108.33 \mathrm{aA}$ & 200 & $20.47 \mathrm{aA}$ & 5.90 & $\mathrm{aB}$ \\
\hline $\mathrm{P}_{4}$ & $1.21 \mathrm{aA}$ & 1.41 & $\mathrm{aA}$ & $96.00 \mathrm{aA}$ & $143.7 \mathrm{aA}$ & $8.36 \mathrm{bA}$ & 2.49 & $\mathrm{aB}$ \\
\hline $\mathrm{P}_{1}$ & $1.46 \mathrm{aA}$ & 1.54 & $\mathrm{aA}$ & 87.14 aA & 115 & $5.44 \mathrm{Ca}$ & 2.77 & $\mathrm{aA}$ \\
\hline $\mathrm{P}_{4} \times \mathrm{P}_{1}$ & $1.36 \mathrm{aA}$ & 1.59 & $\mathrm{aA}$ & $127.78 \mathrm{aA}$ & $161.66 \mathrm{aA}$ & $12.97 \mathrm{aA}$ & 3.38 & $\mathrm{aA}$ \\
\hline $\mathrm{P}_{5}$ & $1.51 \mathrm{bA}$ & 1.61 & $\mathrm{aA}$ & $69.37 \mathrm{aA}$ & $\mathrm{aA}$ & $20.26 \mathrm{aA}$ & 6.49 & $\mathrm{aB}$ \\
\hline $\mathrm{P}_{2}$ & $1.34 \mathrm{bA}$ & 1.24 & $\mathrm{aA}$ & $111.25 \mathrm{aA}$ & $126.25 \mathrm{aA}$ & $12.69 \mathrm{bA}$ & 17.25 & $\mathrm{aA}$ \\
\hline $\mathrm{P}_{5} \times \mathrm{P}_{2}$ & $1.74 \mathrm{aA}$ & 1.75 & $\mathrm{aA}$ & $150.62 \mathrm{aA}$ & $143.75 \mathrm{aA}$ & $12.57 \mathrm{bA}$ & 16.36 & $\mathrm{aA}$ \\
\hline $\mathrm{P}_{5}$ & $1.51 \mathrm{aA}$ & 1.61 & $\mathrm{aA}$ & $69.37 \mathrm{aA}$ & $\mathrm{aA}$ & $20.26 \mathrm{aA}$ & 6.49 & $\mathrm{aB}$ \\
\hline $\mathrm{P}_{3}$ & $1.37 \mathrm{aA}$ & 1.80 & $\mathrm{aA}$ & $91.50 \mathrm{aA}$ & 175 & $11.68 \mathrm{bA}$ & 6.05 & $\mathrm{aA}$ \\
\hline $\mathrm{P}_{5} \times \mathrm{P}_{3}$ & $1.60 \mathrm{aA}$ & 1.83 & $\mathrm{aA}$ & 76.90 aA & $163.75 \mathrm{aA}$ & $21.40 \mathrm{aA}$ & 11.93 & $\mathrm{aB}$ \\
\hline $\mathrm{P}_{5}$ & $1.51 \mathrm{aA}$ & 1.61 & $\mathrm{aA}$ & $69.37 \mathrm{aA}$ & $\mathrm{aA}$ & $20.26 \mathrm{aA}$ & 6.49 & $\mathrm{aB}$ \\
\hline $\mathrm{P}_{1}$ & $1.46 \mathrm{aA}$ & 1.54 & $\mathrm{aA}$ & 87.14 aA & 115 & $5.44 \mathrm{cA}$ & 2.77 & $\mathrm{aB}$ \\
\hline $\mathrm{P}_{5} \times \mathrm{P}_{1}$ & $1.49 \mathrm{aA}$ & 1.64 & $\mathrm{aA}$ & $96.87 \mathrm{aA}$ & 165 & $10.32 \mathrm{bA}$ & 4.59 & $\mathrm{bB}$ \\
\hline
\end{tabular}

Means followed by the same uppercase letter in rows and lowercase letter in columns do not differ, according to the ScottKnott test at $5 \%$ probability.

Thus, observation of some morphological characteristics was not effective in identifying the nematode resistance of the genotypes. Therefore, the performance of genotypes should be examined according to their greater or lesser ability to inhibit the reproduction of nematodes. There was large variation between genotypes with regard to the averages of the reproduction factor (1.48 to 7.5$)$ and the number of eggs $(7,725$ and 39,033.41) (Table 2).
It was found that the two variables express the same situation with regard to the nematode resistance of the genotype, and that the egg count is accurate, as it is used to estimate the RF and allow for a classification of genotypes in accordance with their level of resistance to the nematode (MOURA; REGIS, 1987; BRITO et al., 2003; COSTA FILHO, 2012). 
Table 2. Correlation coefficient values for the association between the variables of aerial plant length (LAP), fresh mass of the aerial part (FMAP), root fresh mass (RFM), number of eggs (NE), and reproduction factor (RF) of inoculated watermelon plants.

\begin{tabular}{cccccc}
\hline & LAP & FMAP & RFM & NE & RF \\
\hline CPA & - & $0.186^{*}$ & $0.362^{* *}$ & $0.106^{*}$ & $0.106^{*}$ \\
MFPA & & -1.18 & $-0.305^{* *}$ & $-0.305^{* *}$ \\
MFR & & & $0.471^{* *}$ & $0.471^{* *}$ \\
NO EGGS & & & & $1,000^{* *}$ \\
RF & & & & \\
\hline
\end{tabular}

For length of the aerial part of the plant (LAP), the coefficient of correlation with the other variables was significant and positive, despite weak correlations. This also occurred, but negatively, with the correlations of fresh mass of the aerial part (FMAP) to the other variables (Table 2). The root fresh mass (RFM) was also significant in relation to the number of eggs (NE) and the reproduction factor (RF). Moreover, the coefficient of correlation between the variables $\mathrm{NE}$ and RF was $1.00^{* *}$, indicating a perfect correlation. Costa Filho (2012) also found a weak but significant correlation between RFM and RF. Thus, the use of the morphological characteristics evaluated in this study does not allow the genotype to be discerned, and the data confirm that egg count is the best alternative for assessing the resistance of watermelon genotypes against nematodes.

The only hybrid combination that did not differ from its parent plants with regard to nematode resistance was the hybrid $\mathrm{P}_{5} \times \mathrm{P}_{3}$ (Table 3 ), although the other five $F_{1 s}$ differed from each other in their performances. For example, some $F_{1 s}$ proved to be equal to one parent and superior to the other parent $\left(\begin{array}{lll}\mathrm{P}_{4} & \mathrm{P} & \mathrm{P}_{2} \text { and } \mathrm{P}_{5} \times \mathrm{P}_{2}\end{array}\right)$, others were different from both parents $\left(\mathrm{P}_{4} \times \mathrm{P}_{1}\right.$ and $\left.\mathrm{P}_{5} \times \mathrm{P}_{1}\right)$, and the hybrid $\mathrm{P}_{4}$ $\mathrm{x} \quad \mathrm{P}_{3}$ showed a much higher RF than both of its parents (Table 3). The data show that the combination of parents with different nematode resistance abilities influenced the hybrid combinations, sometimes increasing the plant's allowance for the reproduction of nematodes, as with $\mathrm{P}_{4} \mathrm{X} \mathrm{P}_{3}$, and sometimes reducing it, as occurred in $\mathrm{F}_{1 \mathrm{~s}} \mathrm{P}_{4} \times \mathrm{P}_{2}$ and $\mathrm{P}_{5} \times \mathrm{P}_{2}$ (Table 3 ). When observing heterosis and heterobeltiosis of $F_{1 s}$, this same trend was observed (Table 3). Thus, the data presented show that there is gene complementarity between the parents with regard to nematode resistance of the respective $F_{1 s}$.

The treatments (parents and $F_{1 s}$ ) were significantly different in both the number of eggs and the reproduction factor (Table 3), and differences were also significant between groups I (susceptible parents) and II (parents with a history of resistance). As expected, no significant differences were observed in the effects of general combining ability (GCA) in group I, up to a certain point, because these were improved cultivars, fairly uniform, and not selected for resistance to nematodes; however, in Group II, the effect was highly significant for both variables, as were the effects of specific combining ability. These results indicate that genetic additive effects were important in the expression of RFs in the parent plants that had a history of nematode resistance (group II - fodder watermelons). The significance observed in the specific combining ability (SCA) indicates that the action of the nematodes on these genotypes is controlled by non-additive gene effects and that it depends on genes with dominant effects and/or epistasis (CRUZ et al., 2012). With regard to the effects of combining ability, values of a smaller magnitude are indicators that the hybrid $F_{1 s}$, among the parents in question, had expected behaviour based on the general combining ability (GCA) of the parents, and that this expected behaviour occurred in this study. On the other hand, high absolute values of $\mathrm{s}_{\mathrm{ij}}$ indicate that the performance of a particular hybrid is better or worse in relation to the expected result based on the GCA of the parents. Parents having the largest GCA may potentially be superior and can be included in breeding programs for selection of new pure lines in later generations (RAMALHO et al., 1993). However, it should be noted that, for the selection of plants with resistance to nematodes, the smaller the GCA, the more promising the parent, because such parents will have a greater ability to inhibit the reproduction of $M$. enterolobii.

With respect to the effects of general combining ability for NE and RF (Table 5), it was found that parents $\mathrm{P}_{1}, \mathrm{P}_{2}$, and $\mathrm{P}_{5}$ had negative values for the NO and RF characteristic, suggesting that hybrids that have one of these parents should inhibit the action of the nematodes. Parents $\mathrm{P}_{3}$ and $\mathrm{P}_{4}$ favoured a greater multiplication of nematodes in the root system of the hybrids, which in fact was observed when the specific combining abilities were estimated, because the hybrid combinations $\mathrm{P}_{4} \times \mathrm{P}_{2}$, $\mathrm{P}_{4} \times \mathrm{P}_{1}, \mathrm{P}_{5} \times \mathrm{P}_{2}$, and $\mathrm{P}_{5} \times \mathrm{P}_{3}$ had lower reproductive capacities for the nematodes found in their root systems (Table 5). 
Table 3. Average number of eggs (NE) and reproduction factor (RF) of inoculated parent watermelon plants and their hybrid $\mathrm{F}_{1}$ progeny.

\begin{tabular}{|c|c|c|}
\hline Treatment & $\mathrm{NE}$ & $\mathrm{RF}$ \\
\hline $\mathrm{P}_{4}$ & $22405.83 \mathrm{a}$ & $4.3 \mathrm{a}$ \\
\hline $\mathrm{P}_{2}$ & $11410.12 \mathrm{~b}$ & $2.19 \mathrm{~b}$ \\
\hline $\mathrm{P}_{4} \times \mathrm{P}_{2}$ & $10033.84 \mathrm{~b}$ & $1.93 \mathrm{~b}$ \\
\hline Heterosis & 59.35 & 29.74 \\
\hline Heterobeltiosis & 87.94 & 88.13 \\
\hline $\mathrm{P}_{4}$ & $22405.83 \mathrm{~b}$ & $4.3 \mathrm{~b}$ \\
\hline $\mathrm{P}_{3}$ & $17673 \mathrm{~b}$ & $3.40 \mathrm{~b}$ \\
\hline $\mathrm{P}_{4} \times \mathrm{P}_{3}$ & $39033.41 \mathrm{a}$ & $7.50 \mathrm{a}$ \\
\hline Heterosis & 194.8 & 192.8 \\
\hline Heterobeltiosis & 220.87 & 220.6 \\
\hline $\mathrm{P}_{4}$ & $22405.83 \mathrm{a}$ & $4.3 \mathrm{a}$ \\
\hline $\mathrm{P}_{1}$ & $7725 \mathrm{c}$ & $1.48 \mathrm{c}$ \\
\hline $\mathrm{P}_{4} \times \mathrm{P}_{1}$ & $13240.62 \mathrm{~b}$ & $2.55 \mathrm{~b}$ \\
\hline Heterosis & 87.89 & 88.24 \\
\hline Heterobeltiosis & 171.4 & 172.3 \\
\hline $\mathrm{P}_{5}$ & $24106.07 \mathrm{a}$ & $4.64 \mathrm{a}$ \\
\hline $\mathrm{P}_{2}$ & $11410.12 \mathrm{~b}$ & $2.19 \mathrm{~b}$ \\
\hline $\mathrm{P}_{5} \times \mathrm{P}_{2}$ & $9253.20 \mathrm{~b}$ & $1.78 \mathrm{~b}$ \\
\hline Heterosis & 52.1 & 52.13 \\
\hline Heterobeltiosis & 81.1 & 81.3 \\
\hline $\mathrm{P}_{5}$ & $24106.07 \mathrm{a}$ & $4.64 \mathrm{a}$ \\
\hline $\mathrm{P}_{3}$ & $17673 a$ & $3.40 \mathrm{a}$ \\
\hline $\mathrm{P}_{5} \times \mathrm{P}_{3}$ & $16405.707 \mathrm{a}$ & $3.16 \mathrm{a}$ \\
\hline Heterosis & 78.53 & 78.6 \\
\hline Heterobeltiosis & 92.3 & 93 \\
\hline $\mathrm{P}_{5}$ & $24106.07 \mathrm{a}$ & $4.64 \mathrm{a}$ \\
\hline $\mathrm{P}_{1}$ & $7725 \mathrm{c}$ & $1.48 \mathrm{c}$ \\
\hline $\mathrm{P}_{5} \times \mathrm{P}_{1}$ & $16255.15 \mathrm{~b}$ & $3.12 \mathrm{~b}$ \\
\hline Heterosis & 102.13 & 102 \\
\hline Heterobeltiosis & 210.42 & 210.81 \\
\hline
\end{tabular}

Group averages followed by the same letter in the columns do not differ according to the Scott-Knott test at 5\% probability.

Table 4. Mean square of the general combining ability (GCA) and specific combining ability (SCA) of parents Citrullus lanatus var. lanatus (Group I) and C. lanatus var. citroides (Group II), for the variables number of eggs (NE) and reproduction factor (RF) in plants inoculated with Meloidogyne enterolobii.

\begin{tabular}{cccc}
\hline Source of variation & DF & NE & RF \\
\hline MS Treatment & 10 & $806470372,63^{* *}$ & $29,82^{* *}$ \\
MS between groups & 1 & $1457959529,1121^{* *}$ & $53,84^{* *}$ \\
MS GCA group I & 1 & $206266811,7^{\mathrm{ns}}$ & $7,6^{\mathrm{ns}}$ \\
MS GCA group II & 2 & $124412057,62^{* *}$ & $2,18^{* *}$ \\
MS SCA & 6 & $652039372,04^{* *}$ & $24,12^{* *}$ \\
MS error & 99 & 93965512,18 & 3,47 \\
\hline
\end{tabular}

${ }^{\mathrm{ns}}$ Not significant; ${ }^{*}$ Significant, at $5 \%$ probability; ** Significant, at $1 \%$ probability, according to F test. 
Table 5. Estimates of the effects of general combining ability (GCA) and specific combining ability (SCA) between both parents of Citrullus lanatus var. lanatus and three C. lanatus var. citroides for the variables of number of eggs (NE) and reproduction factor (RF).

\begin{tabular}{ccc}
\hline & \multicolumn{2}{c}{ General Combining Ability } \\
\hline Progênies & $\mathrm{NE}$ & $\mathrm{RF}$ \\
\hline $\mathrm{P}_{1}$ & $-2388,94$ & $-0,46$ \\
$\mathrm{P}_{2}$ & $-2862,02$ & $-0,55$ \\
$\mathrm{P}_{3}$ & 5250,95 & 1 \\
$\mathrm{P}_{4}$ & 1213,81 & 0,23 \\
$\mathrm{P}_{5}$ & $-1213,81$ & $-0,23$ \\
\hline $\mathrm{F}_{1}:\left(\mathrm{P}_{4} \times \mathrm{P}_{1}\right)$ & $\mathrm{Specific} \mathrm{Combining} \mathrm{Ability}$ & $-0,6$ \\
$\mathrm{~F}_{1}:\left(\mathrm{P}_{4} \times \mathrm{P}_{2}\right)$ & $-3128,94$ & $-1,13$ \\
$\mathrm{~F}_{1}:\left(\mathrm{P}_{4} \times \mathrm{P}_{3}\right)$ & $-5862,65$ & 2,89 \\
$\mathrm{~F}_{1}:\left(\mathrm{P}_{5} \times \mathrm{P}_{1}\right)$ & 15023,96 & $-0,99$ \\
$\mathrm{~F}_{1}:\left(\mathrm{P}_{5} \times \mathrm{P}_{2}\right)$ & 2313,2 & $-0,81$ \\
$\mathrm{~F}_{1}:\left(\mathrm{P}_{5} \times \mathrm{P}_{3}\right)$ & $-4215,67$ & \\
\hline
\end{tabular}

$\mathrm{P}_{1}$ : Progeny of BGCIA 941, $\mathrm{P}_{2:}$ Progeny of BGCIA 240, $\mathrm{P}_{3:}$ Progeny of BGCIA 229, $\mathrm{P}_{4}$ : Progeny of cv. Smile, $\mathrm{P}_{5 \text { : Progeny of BRS Opara }}$

However, the positive effects of specific combining ability (SCA) were observed in combinations $\mathrm{P}_{4} \times \mathrm{P}_{3}$ and $\mathrm{P}_{5} \times \mathrm{P}_{1}$, for $\mathrm{NE}$ and $\mathrm{RF}$ (Table 4), indicating poor performance for the characteristic under study, because the greater the value of the specific combining ability (SCA), the higher the hybrid's performance in promoting the development of nematodes in the root system. The other combinations had negative values, with combinations $\mathrm{P}_{4} \times \mathrm{P}_{2}, \mathrm{P}_{5} \times \mathrm{P}_{3}$, and $\mathrm{P}_{5} \times \mathrm{P}_{2}$, in that order, being the most notable, with a greater ability to inhibit the reproduction of phytonematodes in the plants being studied. Parents with a history of nematode resistance are $\mathrm{P}_{1}, \mathrm{P}_{2}$, and $\mathrm{P}_{3}$, and those with a history of susceptibility are $\mathrm{P}_{4}$ and $\mathrm{P}_{5}$.

It was observed that even with combinations of susceptible parents $\left(\mathrm{P}_{4}\right.$ and $\left.\mathrm{P}_{5}\right)$, or, less frequently, with resistant parents $\left(\mathrm{P}_{5}, \mathrm{P}_{3}\right.$, and $\left.\mathrm{P}_{4}\right)$, when combined, they show negative values for the specific combining ability (SCA). These results indicate that some strategies may be used to advance watermelon breeding in order to obtain plant cultivars that are resistant to nematodes. One of these strategies may be hybrid synthesis. In this case, it will be necessary to start with the parents that present the greatest general combining ability (GCA), as well as specific combining ability (SCA), in order to reduce the number of eggs when crossed. Thus, $\mathrm{P}_{1}, \mathrm{P}_{2}$, and $\mathrm{P}_{5}$ should be chosen based on the GCA, and the hybrid combinations $\mathrm{P}_{4} \times \mathrm{P}_{2}, \mathrm{P}_{4} \times \mathrm{P}_{1}, \mathrm{P}_{5} \times \mathrm{P}_{2}$, and $\mathrm{P}_{5} \times \mathrm{P}_{3}$ should be chosen based on their SCA, as all presented a reduction in the stimulus to the nematode. $\mathrm{P}_{4}$ and $\mathrm{P}_{5}$ are lines from commercial cultivars, and $\mathrm{P}_{5}$ is a line with good fruit characteristics and resistance to powdery mildew caused by the fungus (Podosphaera xanthii). In contrast, $\mathrm{P}_{1}$ (PI 244019), an accession introduced from the United States Department of Agriculture, has very small fruits (around $150 \mathrm{~g}$ ). It has white flesh, is very prolific, slow-growing, and low in sugar. Therefore, in order to obtain good characteristics of both the plant and the fruit, crosses with this parent will require a long period of work involving pre-breeding using some backcrossings to $\mathrm{P}_{4}$, a line of the Smile cultivar with relatively small fruits, good sugar content, and red pulp.

The identification of nematode resistant genotypes may occur through selection in the presence of nematodes, and selection for the characteristics of the plant and the fruit may be done in the field. This process can produce a number of lines, and when they reach a reasonable degree of homozygosity, they may be crossed with lines from the $\mathrm{P}_{4}$ line (a line from the Smile cultivar) and with 
$\mathrm{P}_{5}$ (a line from the Opara cultivar). Combining abilities can then be estimated, and the best combinations will indicate the lines that would need to be selected for the synthesis of hybrids that are nematode resistant. The same system may be used for other promising crossings, because they always include a parent from an improved cultivars such as Smile and Opara. When lines from the $\mathrm{P}_{2}$ and $\mathrm{P}_{3}$ parents, which produce fodder watermelons with long and large fruit, are crossed with lines of commercial cultivars, they should produce lines of fruit with a large, oval shape and with a good percentage of pulp (WEHNER, 2007).

\section{CONCLUSIONS}

The reproduction factor is the characteristic that allows for identification of the resistance of watermelon genotypes to the nematode $M$. enterolobii. In addition, there is a genetic complementarity for such resistance.

\section{ACKNOWLEDGEMENTS}

To the University of the State of Bahia, for offering a sensu stricto postgraduate course in the field of irrigated horticulture;

To the Semi-Arid Research Center of the Brazilian Agricultural Research Corporation (EMBRAPA), for providing the physical infrastructure, materials, and labour to carry out the study; and

To Dr. Flávio de França Souza, for his help with statistical analysis.

\section{REFERENCES}

ALFENAS, A. C.; BRUNE, W. Eletroforese em gel de poliacrilamida. In: ALFENAS, A. C. (Ed). Eletroforese e marcadores bioquímicos em plantas e microrganismos. Viçosa: UFV, 2006. Cap. 4, p. 151-182.

ALMEIDA, E. J. et al. Assinalamentos de Meloidogyne enterolobii em goiabeira e em plantas invasoras no estado de São Paulo, Brasil. Nematologia Brasileira, Piracicaba, v. 35, n. 1, p. 50-52, 2011.

BITENCOURT, N. V.; SILVA, G. S. Reprodução de Meloidogyne enterolobii em Olerícolas. Nematologia Brasileira, Piracicaba, v. 34, n. 3, p. 181-183, 2010.

BRITO, J. A. et al. Host status of selected plant species to Meloidogyne mayaguensis from Flórida.
Nematropica, Flórida, v. 33, n. 2, p. 99, 2003.

CARNEIRO, R. M. D. G. et al. Primeiro registro de Meloidogyne mayaguensis parasitando plantas de tomate e pimentão resistentes à meloidoginose no Estado de São Paulo. Nematologia Brasileira, Piracicaba, v, 30, n. 1, p. 81-86, 2006.

COOLEN, W. A.; D' HERDE, C. J. Method for the quantitative extraction of nematode plant tissue. Belgium: State of Nematology and Entomology research Station, 1972. $77 \mathrm{p}$.

COYNE, D. L. et al. Nematologia prática: Um guia de campo e de laboratório. Cotonou, Benin, SP - IPM Secretariat, International Institute of Tropical Agriculture (IITA), 2007. 93 p.

COSTA FILHO, J. H. Avaliação da reação de acessos de melancia para fitonematoides Meloidogyne enterolobii. Mossoró. 2012. 52 f. Dissertação (Mestrado em Fitotecnia: área de concentração em Agricultura Tropical) Universidade Federal Rural do Semiárido, Mossoró, 2012.

CRUZ, C. D.; VENCONVSKY, R. Comparação de alguns métodos de análise dialélica. Revista Brasileira de Genética, Ribeirão Preto, v. 12, n. 2, p. 425-436, 1989.

CRUZ, C. D. Genes: a software package for analysis in experimental statistics and quantitative genetics. Acta Scientiarum. Agronomy, v. 35, n. 3, p. 271276, 2013,

CRUZ, C. D. et al. Modelos biométricos aplicados ao melhoramento genético. 4. ed. Viçosa, MG: UFV, 2012. 514 p.

FOOD AND AGRICULTURE ORGANIZATION OF THE UNITED NATIONS - FAO. Agricultural production, primary crops. 2012. Disponível em: http:// faostat.fao. org/site/567/ DesktopDefault. aspx?PageID=567\#ancor. Acesso em 30 de outubro de 2015.

GERALDI, I. O.; MIRANDA-FILHO, J. B. Adapted models for the analysis of combining ability of varieties in partial diallel crosses. Revista Brasileira de Genética, Ribeirão Preto, v. 11, n. 2, p. 419-430, 1988.

GORGULHO, E. P.; MIRANDA FILHO, J. B. Estudo da capacidade combinatória de variedades de milho no esquema de cruzamento dialélico parcial. Bragantia, Campinas, v. 60, n. 1, p. 1-8, 2001.

GUIMARÃES, L. M.; P.; MOURA, R. M.; PEDROSA, E. M. R. Parasitismo de Meloidogyne 
mayaguensis em diferentes espécies botânicas. Nematologia Brasileira, Piracicaba, v. 27, n. 2, p 139-145, 2003.

GRIFFING, B. Concept of general and specific combining ability in relation to diallel crossing systems. Australian Journal Biological Science, Australia, v. 9, n. 4, p. 463-493, 1956.

MOURA, R. M.; REGIS, E. M. O. Reações de feijoeiro comum (Phaseolus vulgaris) em relação ao parasitismo de Meloidogyne javanica e M. incognita (Nematoda: Heteroderidae). Nematologia Brasileira, Piracicaba, v. 11, n. 1, p. 215-225, 1987.

LOPES, C. A.; REIS, A.; LIMA, M. F. Principais doenças da cultura da melancia no Brasil.1. ed. Brasília: Embrapa Hortaliças.2008. 10 p. (Circular Técnica, 61).

PONTES, M. F. C. Resistência de melancieira a Meloidogyne mayaguensis, e avaliação dos mecanismos envolvidos. 2009. 69 f. Tese (Doutorado em Fitopatologia: área de concentração virologia). Universidade Federal de Pernambuco, Recife. 2009.

GOMES, P. F. Curso de estatística experimental. 15. ed. Piracicaba: FEALQ, 2009415 p.

QUEIRÓZ, M. A. Germplasm of Cucurbitaceae in Brazil. Crop Breeding and Applied Biotechnology, Viçosa, v. 4, n. 4, p. 377-383, 2004.

RAMALHO, M. A. P. et al. Genética quantitativa em plantas autógamas; aplicações ao melhoramento do feijoeiro. Goiânia, GO: UF, 1993. 217 p.

SANTOS, G. R; et al. Manejo integrado de doenças da melancia. Viçosa, MG: UFV, 2005. 70 p.

SILVEIRA, L. M. et al. Seleção de acessos e progênies de citrullus spp. para resistência a três potyvirus. Fitopatologia Brasileira, Brasília, v. 30, n. 4, p. 394-399, 2005.

WEHNER, T. C. Overview of the genes of watermelon. In: PITRAT, M. (ed). In: Cucurbitaceae 2008, Procedings of the IX 15 ed Eucarpia meeting on genetics and breeding of Cucurbitaceae, 15., 2008, Avignon. Anais... Avignon: INRA, 2008. P.79-80. 